\title{
Assessing the changes in land use and ecosystem services in Changzhou municipality, Peoples' Republic of China, 1991-2006
}

\author{
F. Li ${ }^{\mathrm{a}, *}$, Y.P. Ye ${ }^{\mathrm{b}}$, B.W. Song ${ }^{\mathrm{c}}$, R.S. Wang ${ }^{\mathrm{a}}$, Y. Tao ${ }^{\mathrm{a}}$ \\ a State Key Laboratory of Urban and Regional Ecology, Research Center for Eco-Environmental Sciences, Chinese Academy of Sciences, Beijing 100085, PR \\ China \\ ${ }^{\mathrm{b}}$ College of Hydrology and Water Resource, Hohai University, Nanjing 210098, PR China \\ c Shanghai Academy of Environmental Sciences, Shanghai 200233, PR China
}

\section{A R T I C L E I N F O}

\section{Article history:}

Received 20 June 2013

Received in revised form 25 October 2013

Accepted 8 November 2013

\section{Keywords:}

Urban land use

Open space

Ecosystem services

Urban planning

Urban environment

\begin{abstract}
A B S T R A C T
Much of the world is experiencing fast urbanization. Many peri-urban open spaces, such as parks, forest, farmland, and wetlands, have been built over, which has resulted in a steep decline of ecosystem services at the municipal and regional levels. Using remote sensing, geography information system (GIS) technology and economic evaluation method for ecosystem services, the evolution of landscape spatial structure in 1991, 1996, 2001 and 2006 of Changzhou City, People's Republic of China, was obtained and the change of ecosystem services resulted from land use change was evaluated. Study results show a continuing expansion of urbanized areas and reduction in ecosystem services. Before 2001, farmland was the main type of land use, accounting for more than 53.3\% of the total area within the broadlydrawn municipal boundaries. In 2006, farmland and built-up areas were the main land-use types. The built-up area increased by 122\% from 1991 to 2006. From 1991 to 2001, the proportion of ecological land (farmland, forests, grasslands, and water-covered areas) within Changzhou's municipal boundaries decreased $24.1 \%$. Based on the observed changes, the economic value of ecosystem services provided by Changzhou's ecological land decreased by 19.3\% from 1991 to 2006 and the annual decrease ratio was approximately $1.3 \%$. Conversion of farmland to other uses was responsible for the largest reduction in the value of ecosystem services, equal to 239.8 million RMB (equivalent to USD 37.8 million). Our research results were already adopted locally by Changzhou Municipal Bureau of Urban Planning and applied for Changzhou Mater Urban Planning. The current study can contribute not only to improvements in the Changzhou environment, but to the study of and improvements to other rapidly-urbanizing cities, as the rapid growth of urban areas is one of the most pronounced environmental trends of recent times.
\end{abstract}

(c) 2014 Elsevier Ltd. All rights reserved.

\section{Introduction}

Cities are complex socio-economic-natural ecosystems dominated by human activities, which define land use patterns (Grimm et al., 2008; Ma and Wang, 1984; Wang et al., 2011). Land use in urban areas can be characterized by its physical, ecological, social, and economic attributes. Urban land not only provides a supporting for human economic activities, but also serves as the fundamental basis for ecosystem services (Foley et al., 2005; Li et al., 2005). With the acceleration of urbanization that has occurred during the past century, the increasing demand for built-up area has led to increasingly serious conflicts between various types of land use, and continuous replacement of agricultural land and biodiversity

\footnotetext{
* Corresponding author. Tel.: +86 10 62849103; fax: +86 1062849103.

E-mail addresses: lifeng@rcees.ac.cn (F. Li), yapingye66@hotmail.com (Y.P. Ye), bagetutu@yahoo.cn (B.W. Song),wangrs@rcees.ac.cn (R.S. Wang).
}

hotspots with built-up land in rapid urbanizing areas, such as China, India and pan-tropical Africa (Wang et al., 2004; Seto et al., 2012). This has led to a decline of the ecosystem services provided by open space inside municipal boundaries (Bohnet and Pert, 2010; Güneralp and Seto, 2008; Huang et al., 2009; Jomaa et al., 2008; Li et al., 2010; Pauleit et al., 2005; Su et al., 2010; Sundell-Turner and Rodewald, 2008). It is important that we protect urban open space, such as parks, forest, farmland, and wetlands. Gradual restoration and management of severely damaged zones will be important for improving the service functions of urban land.

Land is the supporter of ecosystem services. Daily (1997) defined ecosystem services from the perspective of a natural ecosystem and classified these services into fifteen categories. Since the publication of the "global value of ecosystem services and natural capital" by Costanza et al. (1997), studies of the value of ecosystem services have become increasingly common (Boyd and Banzhaf, 2007; Brauman et al., 2007; Costanza et al., 1997; Daily, 1997; Daily and Matson, 2008; Daily et al., 2002, 2009; Losey and Vaughan, 2006; 
Wallace, 2007; Wang et al., 2004). Costanza et al. (1997) classified ecosystem services into seventeen functions, including climate and water regulation, erosion control, nutrient cycling, and entertainment and cultural values. In addition, these authors assessed the value of the global ecosystem services and proposed ecosystem service value coefficients for a variety of land types. In 2010, The Economics of Ecosystems and Biodiversity Group published a synthesis report to illustrate how economic concepts and tools can equip society with the means to incorporate the value of nature into decision-making at all levels, and for example, integrate the value of water and wetlands into decision-making (TEEB, 2010, 2013). Since the 1980s, ecologists and economists have conducted many evaluations of the impacts of changes in natural capital and ecosystem services. In China, Xie et al. (2001) modified Costanza's coefficients to account for unique characteristics of the Chinese socioeconomic and environmental ecosystem, and obtained an equivalence table for terrestrial ecosystems (Xie et al., 2001, 2003). Since then, many scholars have assessed the value of different types of ecosystem services for environments such as cities, wetlands, and farmland using Costanza's or Xie's coefficients (Gee and Burkhard, 2010; Huang et al., 2010; Kreuter et al., 2001; Li and Ren, 2008; Tong et al., 2007; Van Eekeren et al., 2010; Wang et al., 2010). Till now, some evaluation approaches and models, such as market valuation, hedonic property price, travel cost, contingent valuation, cost-based approaches, replacement costs, stated preference methods, alternative scenarios and integrated valuation of ecosystem Services and Tradeoffs (InVEST) model, were developed and applied for ecosystem services (Nelson et al., 2009; Gómez-Baggethun et al., 2010; Li et al., 2011; Polasky et al., 2011; Calvet-Mir et al., 2012; Viglizzo et al., 2012; Gómez-Baggethun and Barton, 2013).

Ecosystem services are defined as direct and indirect contributions from ecosystems to human well-being (TEEB, 2010). Urban ecosystem services are defined as those provided by urban ecosystems and their components (Gómez-Baggethun and Barton, 2013). It refer to the ability of an urban ecosystem to provide tangible or intangible natural products, environmental resources, and commonweal that maintain the production, consumption, distribution, restoration, and regulation activities of human society in urban areas (Wang et al., 2004). Ecosystem services provided in urban areas include air purification, climate regulation, noise reduction (Bolund and Hunhammar, 1999; Jansson, 2013), waste treatment, food supply, water flow regulation and runoff mitigation, urban temperature regulation, moderation of environmental extremes, pollination and seed dispersal, recreation and cognitive development, animal sighting and ecosystem disservices (GómezBaggethun and Barton, 2013). Land use and cover change to build cities and support their population drives local to global alterations of primary productivity, biogeochemical cycles, climate, hydrosystems and biodiversity (Alberti, 2005; Grimm et al., 2008). Changes in land use potentially undermine the capacity of ecosystems to sustain food production, maintain freshwater and forest resources, regulate climate and air quality (Foley et al., 2005), Trade-offs between different urban ecosystem services along a rural-urban gradient should be considered during urban planning (Kroll et al., 2012; Larondelle and Haase, 2013; Radford and James, 2013). The millennium ecosystem assessment provided a baseline for ecosystem services studies (MA, 2005a,b) and TEEB (2010) collected knowledge on appropriate valuation methods for ecosystem services. The principles described by both groups guided the design of the present study.

For the purposes of the current study, urban ecological land is defined as a land-use type that provides ecosystem services to the area as a whole and to the urban core in particular. It includes non-built-up areas (open space) such as forest, farmland, parks, grassland, and bodies of water, areas that provide basic ecosystem services (e.g., support, distribution, regulation, and production) necessary to sustain human life and socioeconomic development while providing an acceptable quality of life. The services provided by the land are associated with its natural conditions, such as the types of natural resources that are available, the climate, the soil, and the underlying geology (Li et al., 2009b). However, the services are also determined by human factors that affect these conditions, such as the level of urban development, the direction of development, and the quality of life sought by the urban population ( $\mathrm{Li}$ et al., 2009a,b). The main difference between ecological land and not ecological land is that ecological land is non-built-up land and it is open space and permeable, but not ecological land is built-up area and it is imperious surface cover, which can weaken ecosystem services (Li et al., 2009b).

Researchers in China have mainly studied the definition of ecological land and suitable classification systems (Deng et al., 2005, 2009; Yue and Zhang, 2003). Studies in Western countries have not proposed ecological land as an independent and specialized type of nomenclature, but the concept and related research works of open space, peri-urban open space and non-built-up areas is well recognized. Forest, farmland, parks, grassland, and wetlands, as the main types of ecological land, can provide ecosystem services such as carbon sequestration, nutrient and sediment retention, storm peak mitigation, biodiversity maintenance, crop pollination, and cultural and recreational uses (Costanza et al., 1997; Daily, 1997). Due to urban sprawl, population increase, and intensified human activities, ecological land is threatened by quick urban development, especially in big cities. The degradation and reduction of ecological land inside municipal boundaries weaken urban ecosystem services (Li et al., 2005; Wang et al., 2004).

The objective of the present study was to analyze the dynamic changes in municipal land use and the resulting effects on ecosystem services. To accomplish this, the authors studied the city of Changzhou between 1991 and 2006, using remote sensing data and geographic information system (GIS) technology. During the study period, Changzhou City was undergoing a period of rapid development. Therefore, insights into the relationships between spatial changes in municipal land use and ecosystem services illustrate the kind of scientific approach that will support decision-making to strengthen regional ecosystem services, manage urban and rural land use, and increase the likelihood of sustainable urban development.

Three important research questions are addressed in this paper: (1) How does urban land use influence ecosystem services over time? (2) What changes in the spatial structure and ecosystem services of municipal ecological lands (farmland, forest, bodies of water) have been observed? (3) How to evaluate these changes in ecosystem services?

\section{Materials and methods}

\subsection{Description of the study area}

Changzhou City is located in southeastern PR China, south of the Yangtze River (Fig. 1). The municipality is located between $31^{\circ} 09^{\prime} \mathrm{N}$ and $32^{\circ} 04^{\prime} \mathrm{N}$ and between $119^{\circ} 08^{\prime} \mathrm{E}$ and $120^{\circ} 12^{\prime} \mathrm{E}$. The terrain is slightly higher in the southwest, and slightly lower in the northeast. The geomorphic type is a high sand plain that contains both hills and flat land. The area is characterized by a subtropical, maritime, monsoon, humid climate, with an average annual temperature of $16.3^{\circ} \mathrm{C}$, total annual precipitation of $1069 \mathrm{~mm}$, and an annual total sunshine time of $2035 \mathrm{~h}$. The dominant wind is from the southeast. In 2006, the municipality's total administrative area was $4385 \mathrm{~km}^{2}$, with a population of 3.49 million. The urban area accounts for $1872 \mathrm{~km}^{2}$ ( $42.7 \%$ of the total) and the urban population is 2.17 million (62.2\% of the total). It is divided into five 

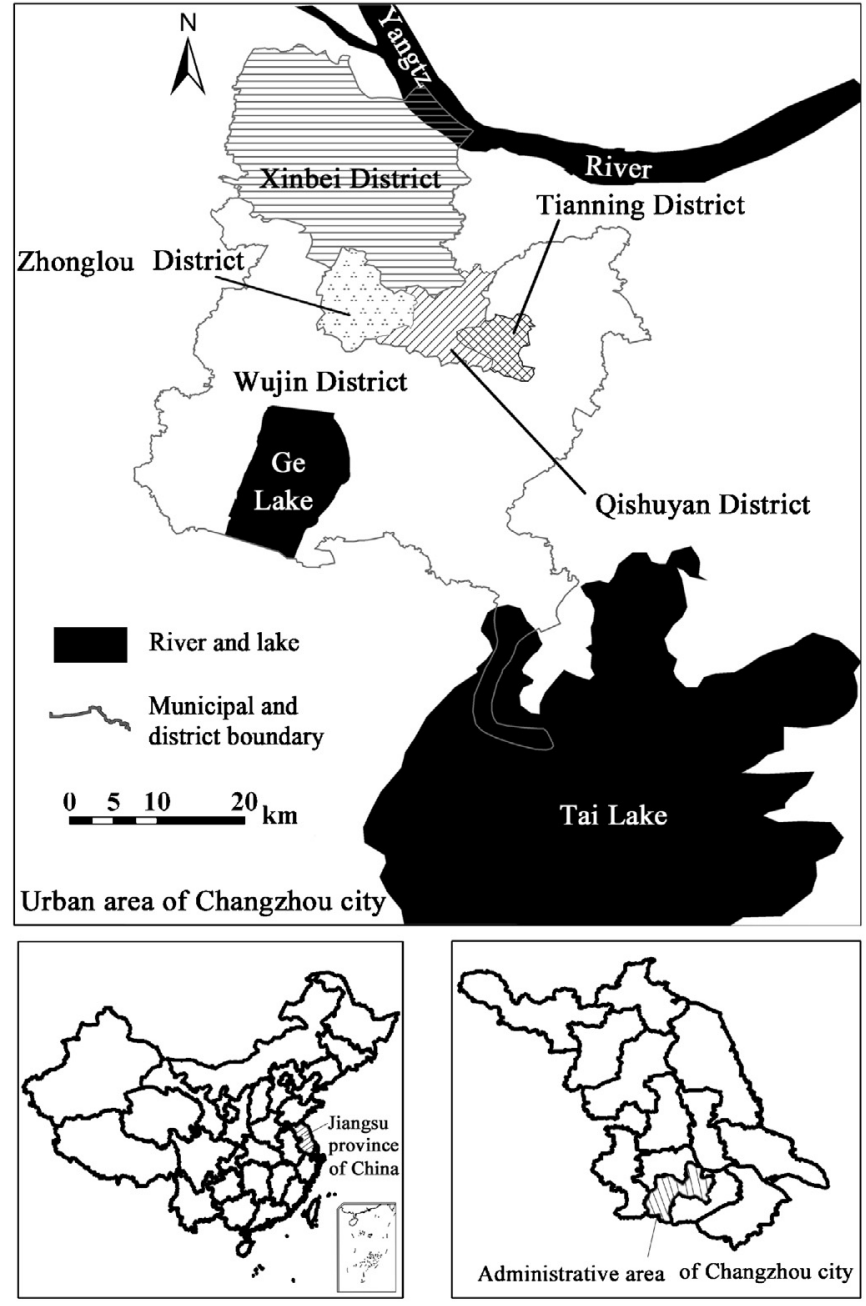

Fig. 1. Location of the study area.

administrative districts: Wujin, Xinbei, Tianning, Zhonglou, and Qishuyan (Fig. 1). The built-up urban area totaled $654 \mathrm{~km}^{2}(14.9 \%$ of the total), with a population of 1.05 million (30.0\% of the total) (Changzhou Municipal Statistical Bureau, 2007).

As these numbers show, the definition of a "city", in a Chinese context, frequently differs from the corresponding Western definition. A Chinese city represents a large and permanent settlement with a dense non-agricultural population and well-developed industries, and has a specific administrative boundary that includes large areas of what would be considered rural in a Western setting; it is therefore more closely equivalent to a "regional municipality". It is often the center of a region's political, economic, and cultural life. The urban, built-up area comprises the part of the city characterized by a high non-agricultural population density and greater dominance by human rather than natural features in comparison with the suburbs and rural areas that surround the urban area. The built-up area is a centralized region with a sealed surface, and is mainly covered by buildings of various types (e.g., commercial and residential areas), and has the highest population density within the city. In this paper, we make a clear distinction between municipal area (which includes both built-up and non-built-up areas) and urban (built-up) area.

\subsection{Data sources and land use classification}

To assess land use changes in the municipality, we obtained Landsat TM and ETM images with a resolution of $30 \mathrm{~m}$ on 23 July
1991, 3 August 1996, 26 July 2001, and 18 September 2006. The municipality's administrative map (1:2000) was used as a reference. Using the methods described in Section 2.3, we classified the study area into forest, farmland, areas covered by bodies of water, and built-up areas (Table 1), using the land use classification system enacted by the Committee of Agricultural Zoning of the People's Republic of China in 1984 (Deng et al., 2005, 2009; Yue and Zhang, 2003).

\subsection{Remote sensing and GIS technology}

Using version 4.5 of the ENVI GIS software, we analyzed the four Landsat images (1991, 1996, 2001, 2006), using supervised classification. To test the quality of the classification results, we conducted a kappa test using ground-based reference information and random sampling. The size of samples (pixels) used for the accuracy assessment was 2695, 2510, 2305, and 2305 for 1991, 1996, 2001, and 2006, respectively, and was different from those used for the classification. The ground-truth verification was performed using stratified random sampling method based on assistant datasets such as the Google Map and a 1:2000 topographic map for Changzhou municipality, as well as local field surveys. The kappa values were $0.72,0.77,0.75$, and 0.82 for 1991, 1996, 2001, and 2006, respectively. All four values were higher than 0.7 , which is the minimal requirement for satisfactory classification (Lucas and Frans, 1994). Further analysis on the spatial patterns of forest, farmland, bodies of water, and built-up areas were processed using version 9.2 of ArcGIS software. We used the following formula to calculate the proportional rate of change for each land-use type:

$\mathrm{C}=\frac{\mathrm{A}_{j}-A_{i}}{A_{i}}$

where $C$ represents the proportional change in a land-use type, and $A_{i}$ and $A_{j}$ represent the area of the land type in years $i$ and $j$, respectively. We used the following formula to calculate the changes per year in each land-use type:

$D=\frac{1}{n_{j}-n_{i}} \cdot \frac{A_{j}-A_{i}}{A_{i}}$

where $D$ represents the change in each land-use type per unit time, and $n_{i}$ and $n_{j}$ represent years $i$ and $j$, respectively.

\subsection{Methods for the evaluation of ecosystem services}

In this study, the previously established methods were used (Xie et al., 2003) to determine the value coefficients for the ecosystem services. The economic value of ecosystem services per unit area of Changzhou municipality was calculated by using the equivalence values developed by Xie et al. (2003) to adjust Costanza's values (Costanza et al., 1997) to account for Chinese social and environmental conditions (Table 2). The urban ecosystem services studied in this paper include food production, raw materials, soil formation and conservation, waste treatment, climate regulation, biodiversity maintenance, water regulation (provisioning of water for agricultural, industrial, or transportation purposes), gas regulation (regulation of atmospheric chemical composition, and recreation. Other ecosystem services in urban areas such as noise reduction, pollination and seed dispersal, and moderation of environmental extremes are not considered in this study due to the difficulty of data availability. The ecosystem service value coefficients for forest, farmland, and bodies of water were obtained from Xie et al. (2003). Value coefficients for built-up areas were obtained from Duan et al. (2005). In this method, farmland is the reference value for all agroecosystems and woodland is the reference value for all forest ecosystems. Bodies of water and wetland areas 
Table 1

Land-use types found within the municipal boundaries of Changzhou City.

\begin{tabular}{|c|c|}
\hline Type of land use & Land descriptions \\
\hline Farmland & $\begin{array}{l}\text { Arable land (irrigated paddy fields, fields on hilltops that depend on rain for water, irrigated land, dry land, vegetable farms), gardens } \\
\text { (orchards, mulberry trees, tea gardens, other gardens), meadows (natural grassland, improved fields of grass, artificial turf) }\end{array}$ \\
\hline Forest & Woodland, shrub land, sparse forest, immature forest, degraded forest, nurseries \\
\hline Bodies of water & Rivers, lakes, reservoirs, ponds, reed wetlands, ditches, hydraulic structures (e.g., canals) \\
\hline Built-up areas & $\begin{array}{l}\text { Residential and industrial land (urban residential, independent industrial and mining land, special land), transportation land } \\
\text { (railways, major and minor roads) }\end{array}$ \\
\hline
\end{tabular}

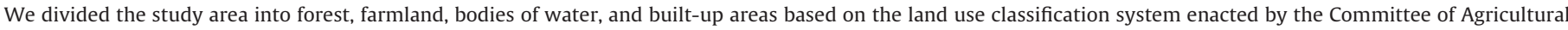
Zoning of the People's Republic of China in 1984 (Deng et al., 2005, 2009; Yue and Zhang, 2003).

were identified in the remote-sensing interpretation. We therefore used a value coefficient for bodies of water that equaled the average of the values for wetlands and water areas. The built-up area was used as the reference value for the ecosystem services of urban and mining areas. It had a negative effect on the net ecosystem services value. Values of $-6678 \mathrm{RMB} / \mathrm{ha}$ for the value of the water regulation function (provisioning of water for agricultural, industrial, or transportation purposes) and $-2174.1 \mathrm{RMB} /$ ha for the value of the waste disposal function in built-up areas were used (Bai and Chen, 2004; Duan et al., 2005; Xie et al., 2003). The formula used to calculate the economic value of ecosystem services was:

$V=\sum A_{i} \times R_{i}$

where $V$ represents the total ecosystem services value, $A_{i}$ represents the area of land type $i\left(\mathrm{~km}^{2}\right)$, and $R_{i}$ represents the value coefficient for the ecosystem services provided by land type $i$.

\section{Results}

\subsection{Changes in the spatial structure of land use in Changzhou's urban area from 1991 to 2006}

Fig. 2 shows the changes in the distribution of land-use types in Changzhou's urban area from 1991 to 2006. In 1991, the builtup area was concentrated along the segment of the Grand Canal that runs through the city. Farms, forests, and bodies of water that provided ecosystem services surrounded the city, with good connections among these areas via green corridors. From 1991 to 2006, the built-up area expanded outwards from the central urban area. Ecological land, especially farmland, was gradually replaced by built-up areas. The connectivity of the ecological network decreased.

The ratio of each land-use type in 1991 was farmland > bodies of water $>$ built-up areas $>$ forest. This had changed to farmland $>$ built-up area $>$ bodies of water $>$ forest by 2006 .

- Forest area decreased by $22.3 \%$ from 1991 to 1996 , representing an annual reduction of $4.5 \%$ (Table 3 ).

- Farmland area decreased by $17.6 \%$ from 2001 to 2006, representing an annual reduction of 3.5\%.

- The water-covered area decreased by $10.9 \%$ from 1996 to 2001 , representing an annual reduction of $2.2 \%$. During the other time periods, this area increased due to good management.

- The built-up area increased rapidly, with the biggest increase, of $66.6 \%$ (13.3\% per year), occurring from 1991 to 1996 (Table 3 ). The decreases in the total area of ecological land, farmland, forest, and bodies of water were $27.0 \%, 32.2 \%, 23.3 \%$, and $8.7 \%$, respectively, from 1991 to 2006.

Before 2001, farmland was the main type of land use, accounting for more than $53.3 \%$ of the total municipal area (Table 2). From 1991 to 2006, farmland area decreased continuously: $381 \mathrm{~km}^{2}$ were transformed into built-up areas. In 2006, farmland and built-up areas were the main land-use types. The built-up area increased by $122 \%$ from 1991 to 2006 (Table 4). The proportion of farmland decreased from $64.9 \%$ in 1991 to $43.9 \%$ in 2006 . The main conversion in land use occurred between farmland and built-up areas (Table 4). Farmland area decreased from $1214 \mathrm{~km}^{2}$ to $822 \mathrm{~km}^{2}$, while the built-up area increased by $451 \mathrm{~km}^{2}$, from $203 \mathrm{~km}^{2}$ to $654 \mathrm{~km}^{2}$. In addition, $97.2 \%$ of the $392-\mathrm{km}^{2}$ decrease in farmland area was transformed into built-up area. From 1991 to 2006, forest and water-covered areas were relatively stable, with minor variations. Forest area decreased by $31 \mathrm{~km}^{2}$ from 1991 to 2001 , amounting to a reduction of $23.3 \%$. The area of forest increased by $11 \mathrm{~km}^{2}$ from 2001 to 2006.

Overall, the fastest growth in built-up area and the fastest reduction in ecological land occurred from 1991 to 1996; the period of second-fastest growth was the period from 1996 to 2001. The growth of built-up area (and consequent reduction in ecological land) slowed down from 2001 to 2006. This was a result of the government's renewed emphasis on ecological planning and the people's increased awareness of the need for ecological protection.

\subsection{Changes in the ecosystem services of farmland}

The main ecosystem services provided by farmland to the Changzhou municipal region were food production, soil formation and conservation, waste treatment, climate regulation, biodiversity maintenance, provisioning of water for agricultural, industrial, or transportation purposes, and gas regulation (regulation of atmospheric chemical composition). The decrease in the total area of farmland and its ecosystem services was 32.2\% from 1991 to 2006 (Tables 3 and 5). According to the Statistical Yearbook of Changzhou City for 2007, the grain yield within the municipal area was 776, 573, and 403 thousand metric tons in 1991, 2001, and 2006, respectively. The population of the Changzhou municipal area was 82.8, 147.8, and 199.3 million in 1991, 2001, and 2006, respectively (Changzhou Municipal Statistical Bureau, 2007). This dramatic population increase, accompanied by a reduction in agricultural area and changes in agricultural

Table 2

Ecosystem service value coefficients for the four main types of land use.

\begin{tabular}{|c|c|c|c|c|}
\hline & Forest & Farmland & Bodies of water & Built-up areas \\
\hline Value coefficient of ecosystem services (Yuan RMB/ha) & 134106.8 & 6114.1 & 48082.7 & -5372.1 \\
\hline
\end{tabular}

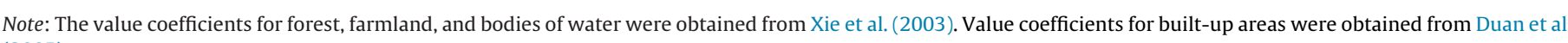
(2005). 

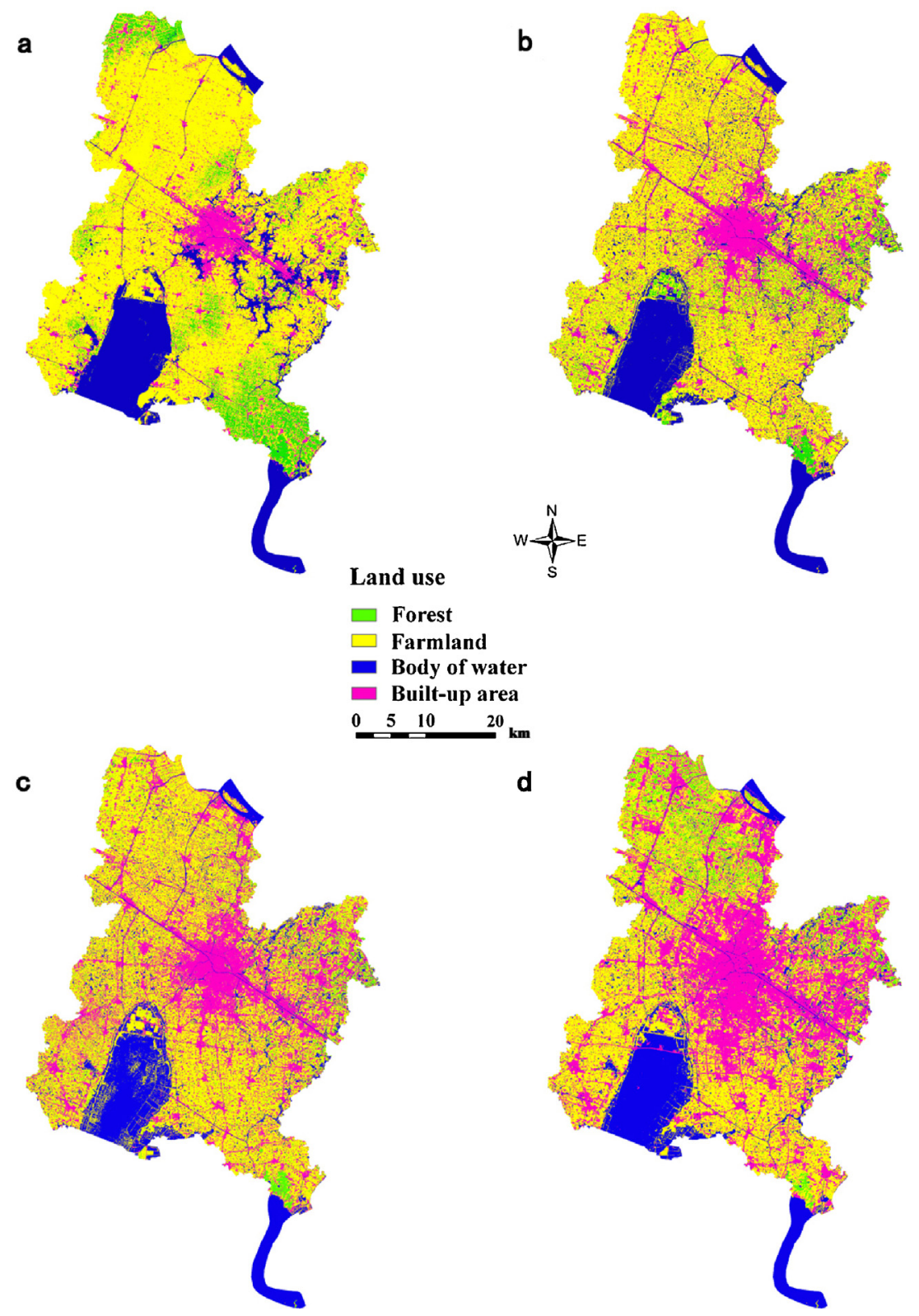

Fig. 2. Land use patterns within the municipal boundaries of Changzhou City in 1991 (a), 1996 (b), 2001 (c), and 2006 (d).

practices (such as choice of crops to grow) resulted in a sharp reduction of food yield per unit area (Fig. 2), which decreased the ability of municipal farmland to provide biological production services, thereby weakening its ecosystem service value (Daily et al., 2009).

\subsection{Changes in forest ecosystem services}

The main ecosystem services provided by the forest lands within the Changzhou municipal boundaries were waste treatment, soil formation and conservation, regulation of atmospheric chemical composition, biodiversity maintenance, water regulation and supply, climate regulation, and raw materials and recreation. The decrease in the total area of forest and its ecosystem services was 23.3\% from 1991 to 2006 (Tables 3 and 5). The forested areas of Changzhou municipality were mainly distributed in the northwestern part of Xinbei District and the southeastern corner of Wujin District (Fig. 2). Because these areas were relatively distant from the main downtown area, they were less strongly affected by urbanization.

Table 3

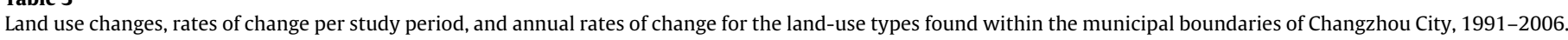

\begin{tabular}{|c|c|c|c|c|c|c|c|c|c|c|}
\hline \multirow[t]{2}{*}{ Type of land use } & \multicolumn{4}{|c|}{ Percentage of total area (\%) } & \multicolumn{3}{|c|}{ Rate of change in proportion (\%) } & \multicolumn{3}{|c|}{ Annual rate of change (\%) } \\
\hline & 1991 & 1996 & 2001 & 2006 & 1991-1996 & 1996-2001 & 2001-2006 & 1991-1996 & 1996-2001 & 2001-2006 \\
\hline Forest & 7.1 & 5.5 & 4.9 & 5.4 & -22.3 & -12.1 & 12.2 & -4.5 & -2.4 & 2.4 \\
\hline Farmland & 64.9 & 58.9 & 53.3 & 44.0 & -9.2 & -9.5 & -17.6 & -1.8 & -1.9 & -3.5 \\
\hline Bodies of water & 17.2 & 17.5 & 15.6 & 15.7 & 1.9 & -10.9 & 0.7 & 0.4 & -2.2 & 0.1 \\
\hline Built-up areas & 10.8 & 18.1 & 26.2 & 34.9 & 66.6 & 45.0 & 33.2 & 13.3 & 9.0 & 6.6 \\
\hline
\end{tabular}


Table 4

Land-use changes within the municipal boundaries of Changzhou City, 1991-2006.

\begin{tabular}{|c|c|c|c|c|c|c|c|}
\hline Type of land use & $\begin{array}{l}\text { Total area in } 1991 \\
\left(\mathrm{~km}^{2}\right)\end{array}$ & $\begin{array}{l}\text { Total area in } 2006 \\
\left(\mathrm{~km}^{2}\right)\end{array}$ & $\begin{array}{l}\text { Increase or } \\
\text { decrease in area } \\
\left(\mathrm{km}^{2}\right)\end{array}$ & $\begin{array}{l}\text { Area converted to } \\
\text { forest, 1991-2006 } \\
\left(\mathrm{km}^{2}\right)\end{array}$ & $\begin{array}{l}\text { Area converted to } \\
\text { farmland, } \\
1991-2006\left(\mathrm{~km}^{2}\right)\end{array}$ & $\begin{array}{l}\text { Area added to } \\
\text { bodies of water, } \\
1991-2006\left(\mathrm{~km}^{2}\right)\end{array}$ & $\begin{array}{l}\text { Area converted to } \\
\text { built-up areas, } \\
1991-2006\left(\mathrm{~km}^{2}\right)\end{array}$ \\
\hline Forest & 133 & 102 & -31 & $\mathrm{X}$ & 81 & 5 & 32 \\
\hline Farmland & 1214 & 822 & -392 & 80 & $X$ & 65 & 424 \\
\hline Bodies of Water & 322 & 294 & -28 & 4 & 54 & $\mathrm{X}$ & 50 \\
\hline Built-up areas & 203 & 654 & 451 & 3 & 42 & 10 & $\mathrm{X}$ \\
\hline Total & 1872 & 1872 & 0 & 87 & 177 & 80 & 506 \\
\hline
\end{tabular}

Decrease in forest area $\left(\mathrm{km}^{2}\right)=$ Forest loss $(-117)+$ forest gain $(87)=-31$.

Decrease in farmland area $\left(\mathrm{km}^{2}\right)=$ Farmland loss $(-569)+$ farmland gain $(177)=-392$

Decrease in water area $\left(\mathrm{km}^{2}\right)=$ Body-of-water loss $(-108)+$ body-of-water gain $(80)=-28$

Increase in built-up areas $\left(\mathrm{km}^{2}\right)=$ Built-up area loss $(-55)+$ built-up-area gain $(506)=451$

The southeastern part of Wujin District was a hilly area that contained a large forest (Fig. 2). Therefore, it played a significant role in reducing soil erosion, increasing water retention, protecting biodiversity, and increasing carbon sequestration and nitrogen fixation (Costanza et al., 1997; Daily, 1997; Wang et al., 2004). The mosaic of the municipality's forested land tended to become more complex because of conversion to other land uses and fragmentation of patches of forest.

\subsection{Changes in the ecosystem services provided by bodies of water}

The main ecosystem services provided by the bodies of water in the Changzhou municipality are waste treatment, climate regulation, water regulation (provisioning of water for agricultural, industrial, or transportation purposes), recreation, biodiversity maintenance, and gas regulation (regulation of atmospheric chemical composition). The decrease in the total water-covered area and its ecosystem services was 8.7\% from 1991 to 2006 (Tables 3 and 5).

The bodies of water within Changzhou's municipal boundaries once possessed a high level of connectivity. They were a dominant feature of the city's landscape. These bodies of water include the Yangtze River in the north, Tai Lake and Ge Lake toward the middle of the territory (Fig. 1), the Beijing-Hangzhou Grand Canal (which runs through the city), and many other small rivers, lakes, and wetlands. From 2004 to 2006, some rivers were filled in by urban construction, blocking their circulation and their connection with other water systems (Changzhou Municipal Statistical Bureau, 2007). This blockage damaged bodies of water (Fig. 2), diminished their original ecosystem services, lessened the circulation of nutrients between water systems, reduced the ability of the water to absorb and dilute wastes, and directly led to deterioration of the aquatic environment and reduction of its ecosystem services. Attracted by the profits to be gained from aquaculture, various entities fenced off large areas of Ge Lake for this purpose. The surface of the lake was fragmented into breeding areas of various sizes, thereby disrupting the lake's integrity.

\subsection{Economic evaluation of changes in ecosystem services}

We estimated the changes in economic values caused by the spatial changes in the patterns of land use using the value coefficients for the ecosystem services provided by each type of land use during the three periods studied (Table 5). Fig. 3 summarizes the spatial distribution of the economic value of ecosystem services in 1991 and 2006.

By 2006, the water-covered areas of the Changzhou municipal region had decreased to a mere $15.7 \%$ of the total area. However, these small areas accounted for $48.3 \%$ of the total ecosystem services value in the municipality. Water-covered areas provided the largest proportion of all ecosystem services for the Changzhou municipal region. Larger and less fragmented bodies of water provided more ecosystem services than smaller or more fragmented bodies of water. In addition, large bodies of water had better selfrepair and self-adjustment capacities. Ge Lake played a significant role in maintaining a high ecosystem service value between 1991 and 2006.

The ecosystem services value of farmland in the Xinbei District decreased dramatically, indicating that urbanization had consumed a large area of farmland. From 1991 to 2006, the total economic value of the ecosystem services provided by this land decreased by $19.3 \%$ and the annual decrease ratio was approximately $1.3 \%$. The value of the ecosystem services decreased by $23.4 \%, 32.3 \%$ and $8.5 \%$ for forest, farmland, and water areas, respectively (Table 5). Farmland conversion into other uses was responsible for the largest reduction in the value of ecosystem services. This reduction was equal to 239.8 million RMB (equivalent to US\$37.8 million based on the 2011 conversion rate).

From 1991 to 2001, the value of ecosystem services provided by forest land decreased. However, from 2001 to 2006, the ecosystem services value provided by forest increased by $12.2 \%$. This was because the government paid more attention to the protection of green space and bodies of water during this period.

During the fifteen years from 1991 to 2006, the loss of ecosystem services value due to the increase in built-up areas continued without abatement. The decrease in the value of the built-up areas in 2006 equalled $12 \%$ of the total change in ecosystem services value

Table 5

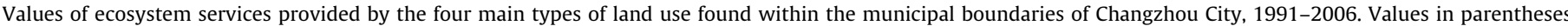
represent the percentage of the total.

\begin{tabular}{|c|c|c|c|c|c|}
\hline \multirow[t]{2}{*}{ Type of land use } & \multicolumn{5}{|c|}{ Economic value of ecosystem services (billions of Yuan RMB) } \\
\hline & 1991 & 1996 & 2001 & 2006 & Change from 1991 to 2006 \\
\hline Forest & $1.78(44.9 \%)$ & $1.38(40.0 \%)$ & $1.22(41.1 \%)$ & $1.37(46.6 \%)$ & -0.41 \\
\hline Farmland & $0.74(18.7 \%)$ & $0.67(19.4 \%)$ & $0.61(20.5 \%)$ & $0.50(17.0 \%)$ & -0.24 \\
\hline Bodies of water & $1.55(39.1 \%)$ & $1.58(45.8 \%)$ & $1.40(47.1 \%)$ & $1.42(48.3 \%)$ & -0.13 \\
\hline Built-up areas & $-0.11(-2.8 \%)$ & $-0.18(-5.2 \%)$ & $-0.26(-8.8 \%)$ & $-0.35(-11.9 \%)$ & -0.24 \\
\hline Total & $3.96(100 \%)$ & $3.45(100 \%)$ & $2.97(100 \%)$ & $2.94(100 \%)$ & -1.02 \\
\hline
\end{tabular}




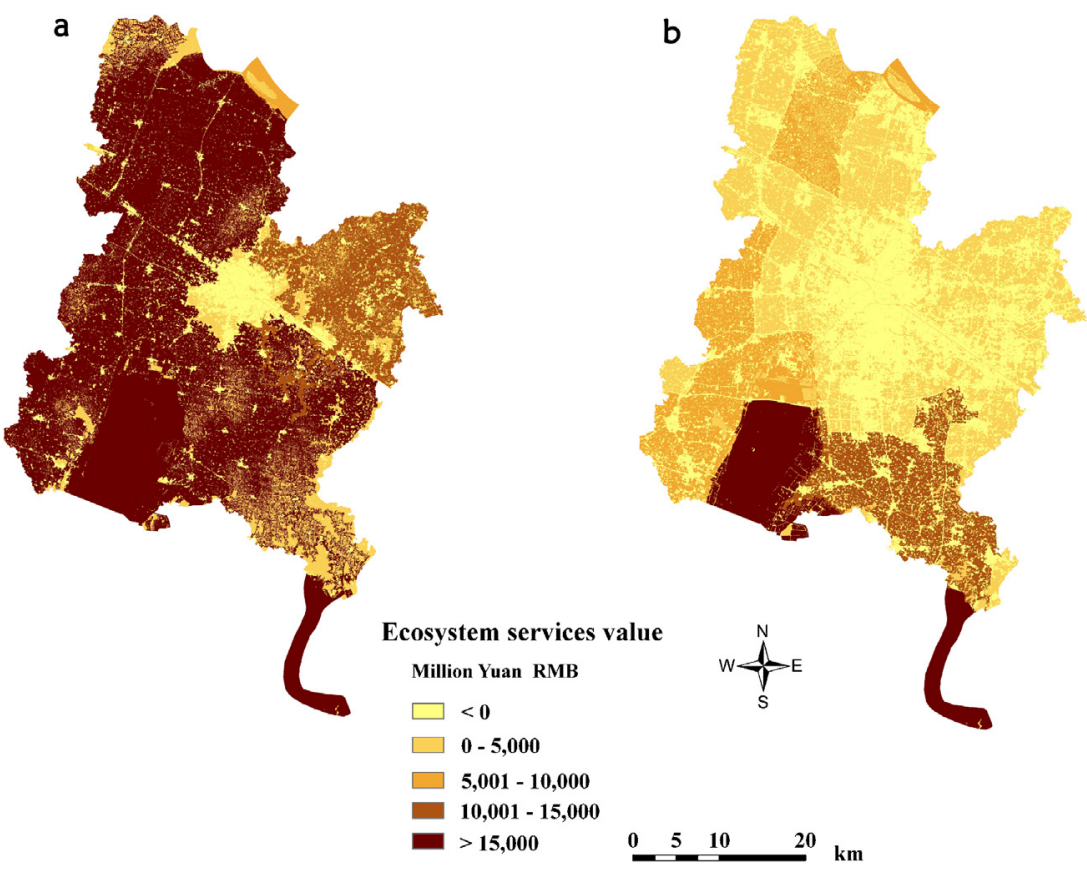

Fig. 3. Distribution of ecosystem services value within the municipal boundaries of Changzhou City, 1991 (a) and 2006 (b).

in Changzhou. From the perspective of ecosystem services, built-up areas were the land-use type responsible for the largest reduction in total municipal ecosystem services. Appropriate control and distribution of built-up areas is therefore a key issue for the managers of future urban development.

\section{Discussion}

The spatial structure of land use in the Changzhou municipal region underwent three stages of development. Before 1991, the area had a single development axis, mainly along the BeijingHangzhou Grand Canal, with four satellite areas. From 1991 to 2001, the built-up areas expanded outwards (primarily northward and southward, but also northwest and southeast along the Grand Canal). From 2001 to 2006, a centralized pattern remained prominent, but development also intensified, radiating outwards from the built-up areas that had developed in previous periods.

Our results clearly show that the overall land-use pattern within Changzhou's municipal boundaries has changed as a result of rapid development in the area. The need to maximize urban social and economic development has been the key issue facing the city's urban planners. However, because of the overwhelming priority attached to economic development, there was little effort to protect ecological land or to devise policies that would protect it. Fortunately, the government has begun to prioritize environmental protection, a policy change that started during the last part of the study period. However, the changes effected by the recent period of rapid growth remain.

The remote sensing data used in this study provided a clear picture of the changes in land utilization during the study period, and let us explore the development of urban land use from the perspectives of its spatial structure and the ecosystem services provided by each type of land use. However, some issues must be addressed in future studies.

First, the use of remote sensing data with a $30-\mathrm{m}$ resolution affected the classification of land-use types. Images with higher resolution would provide more accurate results. Because we focused on comparing the relative changes for each land use in each period, the absolute area of each land use would not greatly affect our overall conclusions, but for detailed planning, greater topographic accuracy would be helpful.

Second, the economic value of ecosystem services must be evaluated more accurately. In this study, we used the economic value coefficients proposed by Xie et al. (2003, 2010), which were based on values from around the world. These were then adjusted to account for Chinese socioeconomic and environmental conditions. It is possible that our results are precise but not accurate estimates of the true value of ecosystem services. Using values based on research within urban areas would provide a more accurate basis to support decision-makers. Changing the coefficients would not necessarily affect the percentage changes we observed (Cheng et al., 2011). Economic valuation of ecosystem services increases in cost with increases in the spatial scale and resolution at which biophysical quantification is required, and with the policy requirements for accuracy and reliability at specific locations within heterogeneous urban landscapes (Gómez-Baggethun and Barton, 2013).

Third, some ecosystem services (e.g., esthetics and culture) cannot be easily evaluated by estimating only their economic values. Future research should look for ways to assess esthetic and cultural ecosystem services and account for them in the analysis.

However, the authors of this study believe that, notwithstanding the need for methodological improvements (as is always the case in a new field of study), the current results will be of use to other scientists investigating rapid urbanization and its environmental effects, as well as to national and local legislators, planners, and government workers.

New legislation is one of the most important steps that the PRC government can undertake to protect ecological land in rapidlyurbanizing regions. Good legislation and planning must be based on accurate knowledge of the current state of local and national ecosystems. The legal status of non-built-up land should be clearly defined, upgraded, and strengthened against hasty, ill-considered land-use conversions. Legislative enforcement is also important. New government departments may be necessary to protect and manage ecological land and the ecosystem services it provides. The integrity and continuity of urban ecological land and other green infrastructure should be maintained and enhanced in order to protect the quality of life in municipal areas. 
However, there are several challenges that stand in the way of easy answers to these questions. First of all, from the conceptual viewpoint, it is difficult to define basic terms in urban ecology, such as city, municipality, urban, built-up areas and ecological land. There are often misconceptions and misunderstanding for theses concepts and definitions (MacGregor-Fors, 2011). Secondly, from the methodological viewpoint, the current methods of material and economic value assessment still need improvement if they are to be useful in evaluating changes in ecosystem services resulting from urban land use change. The temporal and spatial scale for the study of changes in urban land use and ecosystem services is a basic and important problem. Thirdly, from the technical viewpoint, technologies such as remote sensing and GIS must be improved and integrated with other useful tools. Fourthly, from the public viewpoint, more non-governmental stakeholders (from urban dwellers to businesses and NGOs) must be involved in the protection of urban ecological land and ecosystem services. Finally, from a political viewpoint, government must take a stronger and more consistent role in dealing with these problems.

In order to answer these questions in the face of such challenges, a conceptual and methodological framework has already been partially developed and will be improved in the next step of on-going research. For example, definitions of city, municipality, urban, builtup areas, and ecological land are clearly different in the Chinese context and differ in many ways from the corresponding Western definitions cited in this paper. These differences will be spelled out in greater detail. This paper studied the period from 1991 to 2006; the next step will extend the time scale to 1986-2011 and will further analyze the dynamic changes in the spatial structure and ecosystem services of ecological lands. Our research results were already adopted locally by Changzhou Municipal Bureau of Urban Planning and applied for Changzhou Mater Urban Planning. For example, some wetlands nearby Ge Lake, Tai Lake and Yangtz rivers were protected in Changzhou Mater Urban Planning and Land Use Planning based on our research results. The project is aiming for a more comprehensive model integrating environment, economic, social and cultural factors to meet the challenges of fast urbanization. It will be tracking several under-studied changes in ecosystem services to urbanized areas, such as changes to carbon stocks and increased incidence of flooding due to water runoff from impervious surfaces in built-up areas. Finally, from a political viewpoint, the project will be submitting results to the relevant government bodies, in hopes that governmental understanding and intelligent action on these problems will be strengthened in the future.

We thus propose that standardization of basic terms and definitions for the study of urban ecosystems, recording and analysis of the temporal and spatial dimensions of land use, evaluation methods and model application of ecosystem services, public participation, and government regulation will play a crucial role in evaluating and protecting urban and regional ecosystem services.

\section{Conclusion}

The Changzhou municipality has evolved from a landscape pattern dominated by farmland to one dominated by built-up areas. From 1991 to 2006, the spatial structure and total area of ecological land has changed dramatically. The proportion of the total municipal area consisting of ecological land decreased by 24.1 percentage points, from $89.2 \%$ to $65.1 \%$, during the fifteen-year study period. The biggest reduction (from $64.9 \%$ to $43.9 \%$ ) was in farmland, resulting in a $32.3 \%$ decrease in the value of farmland ecosystem services. The overall value of ecosystem services provided by ecological land decreased by $9.3 \%$. Bodies of water were the most important landuse type for ecosystem services in Changzhou municipality. The ecosystem services provided by this type accounted for $48.3 \%$ of the total ecosystem services value, even though it was only $15.7 \%$ of the total Changzhou municipal area.

The current study can contribute not only to improvements in the Changzhou environment, but to the study of and improvements to other rapidly-urbanizing cities. Research on urban ecosystem services should broaden its present focus on biophysical and economic measurement so as to better capture and articulate non-economic values in decision making and planning (Gómez-Baggethun and Barton, 2013). Land use and ecosystem services should be combined and consistently integrated to support decision-making processes at municipality, metropolitan and region levels.

\section{Acknowledgments}

This research was financially supported by the National Natural Science Foundation of China (71273254). We thank Dr. Geoff Hart and Karen Lofstrom for their constructive suggestions for correcting and polishing the manuscript.

\section{References}

Alberti, M., 2005. The effects of urban patterns on ecosystem function. Int. Reg. Sci. Rev. 28 (2), 168-192.

Bai, X.F., Chen, H.W., 2004. The changes of ecosystem services and their values in various constructions of land use-a case study from Yijinhuoluo County of Inner Mongolia. Chin. J. Eco-Agric. 12 (1), 180-182 (in Chinese).

Bohnet, I., Pert, P., 2010. Patterns, drivers and impacts of urban growth-a study from Cairns, Queensland, Australia from 1952 to 2031. Landsc. Urban Plan. 97 (4), 239-248.

Bolund, P., Hunhammar, S., 1999. Ecosystem services in urban areas. Ecol. Econ. 29 293-301.

Boyd, J., Banzhaf, S., 2007. What are ecosystem services? The need for standardized environmental accounting units. Ecol. Econ. 63 (2-3), 616-626.

Brauman, K., Daily, G., Duarte, T., Mooney, H., 2007. The nature and value of ecosystem services: an overview highlighting hydrologic services. Annu. Rev. Environ. Resour. 32 (1), 67-98.

Calvet-Mir, L., Gómez-Baggethun, Erik., Reyes-García, V., 2012. Beyond food production: ecosystem services provided by home gardens. A case study in Vall Fosca, Catalan Pyrenees, Northeastern Spain. Ecol. Econ. 74, 153-160.

Changzhou Municipal Statistical Bureau, 2007. Changzhou Statistical Yearbook 2006. Changzhou Municipal Statistical Bureau, Changzhou, China, pp. 1-30 (in Chinese).

Cheng, L., Li, F., Deng, H.F., 2011. Dynamics of land use and its ecosystem services in China's megacities. Acta Ecol. Sin. 31 (20), 6194-6203 (in Chinese).

Costanza, R., d’Arge, R., De Groot, R., Farber, S., Grasso, M., Hannon, B., Limburg, K., Naeem, S., O'Neill, R., Paruelo, J., 1997. The value of the world's ecosystem services and natural capital. Nature 387 (6630), 253-260.

Daily, G., 1997. Nature's Services: Societal Dependence on Natural Ecosystems. Island Press, Washington, DC.

Daily, G., Ellison, K., Myers, N., 2002. The New Economy of Nature. Island Press, Washington, DC.

Daily, G., Matson, P., 2008. Ecosystem services: from theory to implementation. Proc. Natl. Acad. Sci. U.S.A. 105 (28), 9455-9456.

Daily, G., Polasky, S., Goldstein, J., Kareiva, P., Mooney, H., Pejchar, L., Ricketts, T. Salzman, J., Shallenberger, R., 2009. Ecosystem services in decision making: time to deliver. Front. Ecol. Environ. 7 (1), 21-28.

Deng, H.B., Chen, C.D., Liu, X., Wu, G., 2009. Conception and function classification of regional ecological land. Acta Ecol. Sin. 29 (3), 1519-1524 (in Chinese).

Deng, X.W., Sun, Y.C., Han, S.J., 2005. General principles of urban ecological land classification and planning. Chin. J. Appl. Ecol. 16 (10), 2003-2006 (in Chinese).

Duan, R.J., Hao, J.M., Wang, J., 2005. Study on changes of land-use structure and ecoservice function value-a case study for Datong, Shanxi Province. Ecol. Econ. 3, 60-64, in Chinese.

Foley, J.A., DeFries, R., Asner, G.P., Barford, C., Bonan, G., Carpenter, S.R., Chapin, F.S Coe, M.T., Daily, G.C., Gibbs, H.K., Helkowski, J.H., 1 Holloway, T., Howard, E.A. Kucharik, C.J., Monfreda, C., Patz, J.A., Prentice, I.C., Ramankutty, N., Snyde, P.K., 2005. Global consequences of land use. Science 309, 570-574.

Gee, K., Burkhard, B., 2010. Cultural ecosystem services in the context of offshore wind farming: a case study from the west coast of Schleswig-Holstein. Ecol. Complex. 7 (3), 349-358.

Gómez-Baggethun, E., Barton, D.N., 2013. Classifying and valuing ecosystem services for urban planning. Ecol. Econ. 86, 235-245.

Gómez-Baggethun, E., de Groot, R., Lomas, P., Montes, C., 2010. The history of ecosystem services in economic theory and practice: from early notions to markets and payment schemes. Ecol. Econ. 69, 1209-1218.

Grimm, N.B., Faeth, S.H., Golubiewski, N.E., Redman, C.L., Wu, J.G., Bai, X.M., Briggs, J.M., 2008. Science 319, 756-760. 
Güneralp, B., Seto, K., 2008. Environmental impacts of urban growth from an integrated dynamic perspective: a case study of Shenzhen, South China. Global Environ. Change 18 (4), 720-735.

Huang, S., Wang, S., Budd, W., 2009. Sprawl in Taipei's peri-urban zone: responses to spatial planning and implications for adapting global environmental change. Landsc. Urban Plan. 90 (1-2), 20-32.

Huang, X., Chen, Y., Ma, J., Chen, Y., 2010. Study on change in value of ecosystem service function of Tarim River. Acta Ecol. Sin. 30 (2), 67-75.

Jansson, Å., 2013. Reaching for a sustainable, resilient urban future using the lens of ecosystem services. Ecol. Econ. 86, 285-291.

Jomaa, I., Auda, Y., Abi Saleh, B., Hamzé, M., Safi, S., 2008. Landscape spatial dynamics over 38 years under natural and anthropogenic pressures in Mount Lebanon. Landsc. Urban Plan. 87 (1), 67-75

Kreuter, U.P., Harris, H.G., Matlock, M.D., Lacey, R.E., 2001. Change in ecosystem service values in the San Antonio area. Texas Ecol. Econ. 39 (3), 333-346.

Kroll, F., Müller, F., Haase, D., Fohrer, N., 2012. Rural-urban gradient analysis of ecosystem services supply and demand dynamics. Land Use Policy 29, 521-535.

Larondelle, N., Haase, D., 2013. Urban ecosystem services assessment along a rural-urban gradient: a cross-analysis of European cities. Ecol. Indic. 29, 179-190.

Li, F., Liu, X., Hu, D., Wang, R., Yang, W., Li, D.,Zhao, D.,2009a. Measurement indicators and an evaluation approach for assessing urban sustainable development: a case study for China's Jining City. Landsc. Urban Plan. 90 (3-4), 134-142.

Li, F., Liu, X.S., Zhao, D., Wang, B.B., Jin, J.S., Hu, D., 2011. Evaluating and modeling ecosystem service loss of coal mining: a case study of Mentougou district of Beijing, China. Ecol. Complex. 8, 139-143.

Li, F., Yang, W.R., Zhang, X.F., Wang, R.S., 2009b. Urban ecological land and improvements of ecosystem servcies in Changzhou city, ChinaChina Population. Resour Environ. 19 (special issue), 343-347 (in Chinese)

Li, F., Wang, R., Paulussen, J., Liu, X., 2005. Comprehensive concept planning of urban greening based on ecological principles: a case study in Beijing, China. Landsc. Urban Plan. 72 (4), 325-336.

Li, J., Ren, Z.Y., 2008. Changes in ecosystem service values on the Loess Plateau in Northern Shaanxi Province, China. Agric. Sci. China. 7 (5), 606-614.

Li, Y., Zhu, X., Sun, X., Wang, F., 2010. Landscape effects of environmental impac on bay-area wetlands under rapid urban expansion and development policy: case study of Lianyungang, China. Landsc. Urban Plan. 94 (3-4), 218-227.

Losey, J., Vaughan, M., 2006. The economic value of ecological services provided by insects. BioScience 56 (4), 311-323.

Lucas, I.F.J., Frans, J.M., 1994. Accuracy assessment of satellite derived land-cove data: a review. Photogramm. Eng. Rem. Sens. 60 (4), 410-432.

Ma, S.J., Wang, R.S., 1984. Social-economic-natural complex ecosystems. Acta Ecol. Sin. 4 (1), 1-9, in Chinese.

MacGregor-Fors, I., 2011. Misconceptions or misunderstandings? On the standardization of basic terms and definitions in urban ecology. Landsc. Urban Plan. 100 347-349.

MA, Millennium Ecosystem Assessment, 2005a. Urban systems. Current state \& trends, vol. 1 (Chapter 27).

MA, Millennium Ecosystem Assessment, 2005b. Changes in Ecosystem Services an Their Drivers Across the Scenarios. Scenarios, vol. 2. Millennium Ecosysten Assessment, Chapter 9

Nelson, E., Mendoza, G., Regetz, J., Polasky, S., Tallis, H., Cameron, D.R., Chan, K.M.A. Daily, G., Goldstein, J., Kareiva, P., Lonsdorf, E., Naidoo, R., Ricketts, T.H., Shaw, M.R., 2009. Modeling multiple ecosystem services, biodiversity conservation, commodity production, and tradeoffs at landscape scales. Front. Ecol. Environ. 7 (1), 4-11.

Polasky, S., Nelson, E., Pennington, D., Johnson, K.A., 2011. The Impact of land-use change on ecosystem services, biodiversity and returns to landowners: a case study in the State of Minnesota. Environ. Resour. Econ. 48, 219-242.

Pauleit, S., Ennos, R., Golding, Y., 2005. Modeling the environmental impacts of urban land use and land cover change-a study in Merseyside, UK. Landsc. Urban Plan. $71(2-4), 295-310$.

Radford, K.G., James, P., 2013. Changes in the value of ecosystem services along a rural-urban gradient: a case study of Greater Manchester, UK. Landsc. Urban Plan. 109, 117-127.

Seto, K.C., Güneralp, B., Hutyra, L.R., 2012. Global forecasts of urban expansion to 2030 and direct impacts on biodiversity and carbon pools. Proc. Natl. Acad. Sci., http://dx.doi.org/10.1073/pnas.1211658109, Early edition published online before print September 17, 2012.

Su, W., Gu, C., Yang, G., Chen, S., Zhen, F., 2010. Measuring the impact of urban sprawl on natural landscape pattern of the Western Taihu Lake watershed China. Landsc. Urban Plan. 95 (1-2), 61-67.

Sundell-Turner, N., Rodewald, A., 2008. A comparison of landscape metrics for conservation planning. Landsc. Urban Plan. 86 (3-4), 219-225.

TEEB (The Economics of Ecosystems and Biodiversity), 2010. Mainstreaming the Economics of Nature: A Synthesis of the Approach, Conclusions and Recommendations of TEEB. UNEP, Geneva, Switzerland.

TEEB (The Economics of Ecosystems and Biodiversity), 2013. The Economis of Ecosystems and Biodiversity for Water and Wetlands. Institute for European Environmental Policy (IEEP) \& Ramsar Secretariat.

Tong, C., Feagin, R.A., Lu, J., Zhang, X., Zhu, X., Wang, W., He, W., 2007. Ecosystem service values and restoration in the urban Sanyang wetland of Wenzhou. China. Ecol. Eng. 29 (3), 249-258.

Van Eekeren, N., de Boer, H., Hanegraaf, M., Bokhorst, J., Nierop, D., Bloem, J. Schouten, T., de Goede, R., Brussaard, L., 2010. Ecosystem services in grassland associated with biotic and abiotic soil parameters. Soil Biol. Biochem. 42 (9), $1491-1504$

Viglizzo, E.F., Paruelo, J.M., Laterra, P., Jobbágy, E.G., 2012. Ecosystem service evaluation to support land-use policy. Agric. Ecosyst. Environ. 154, 78-84.

Wallace, K., 2007. Classification of ecosystem services: problems and solutions. Biol. Conserv. 139 (3-4), 235-246.

Wang, G., Fang, Q., Zhang, L., Chen, W., Chen, Z., Hong, H., 2010. Valuing the effects of hydropower development on watershed ecosystem services: case studies in the Jiulong River Watershed. Fujian Province, China. Estuar. Coast. Shelf S. 86 (3), 363-368.

Wang, R.S., Hu, D., Wang, X.R., Tang, L.J., 2004. Urban Eco-services. China Meteorological Press, Beijing, pp. 20-29 (in Chinese)

Wang, R.S., Li, F., Hu, D., Li, B.L., 2011. Understanding eco-complexity: social-economic-natural complex ecosystem approach. Ecol. Complex. 8, $15-29$.

Xie, G.D., Zhen, L., Lu, C.X., Xiao, Y., Li, W.H., 2010. Applying value transfer method for eco-service valuation In China. J. Resour. Ecol. 1 (1), 51-59.

Xie, G.D., Lu, C.X., Cheng, S.K., 2001. Progress in evaluating global ecosystem services. Resour. Sci. 23 (6), 5-9 (in Chinese)

Xie, G.D., Lu, C.X., Leng, Y.F., Zhen, D., Li, S.C., 2003. Ecological assets valuation of the Tibetan Plateau. J. Nat. Resour. 18 (2), 189-196 (in Chinese).

Yue, J., Zhang, X.M., 2003. A discussion of the classification of land use in China. Arid Land Geogr. 26 (1), 78-88 (in Chinese). 